\title{
PENINGKATAN KEMAMPUAN KONEKSI MATEMATIK DAN SIKAP POSITIF SISWA DENGAN PEMBELAJARAN KONTEKSTUAL PADA SISWA SMK PELAYARAN SAMUDERA INDONESIA MEDAN
}

\author{
Taruli Marito Silalahi \\ Universitas Sari Mutiara Medan \\ taruli766hi@gmail.com
}

\begin{abstract}
This research aimed study to determine: 1) the increasing ability of mathematic connection and student's positive thingking by using Contextual Learning are higher than students or usual learning approach.2) there was the interaction between learning by students mathematic ability toward the increasing ability of mathematic connection and student's positive thinking. 3) to determine how the answering process are made by the students in problem solving by using contextual learning and usual learning approach. This kind of research is the quasi experiment. The populations of this research are all of the students in $X$ grade of Tehnical High School with acreditation B where is in Medan and the sample is chosen random sample. Where SMK Medan consist of X Nautic as experiment class and X Tehnical as control class am each consist of 34 students. The instrument used consist of: (1) test students initial mathematic ability, (2) test for mathematic connection and (3) scale for positive thingking, the subject up space. Data analysis are done by using ANAVA two ways. The result of this research shown that (1) the increasing ability in mathematic connection and student's positive thinking by using Contextual Learning is higher than using student's usual thinking approach, (2) there were no interaction between learning and student's ability level to the increasing ability of mathematics and student's positive thinking. The researcher suggests to use the Contextual Learning as the alternative way for teachers to increase the ability of mathematic connection and student's positive thingking.
\end{abstract}

Keyword: Contextual Learning, Mathematical Connection Ability, and Positive Student Attitudes

\begin{abstract}
Abstrak. Penelitian ini bertujuan untuk mengetahui: 1) peningkatan kemampuan koneksi matematika dan hasil berpikir positif siswa dengan menggunakan Pembelajaran Kontekstual lebih tinggi daripada siswa atau pendekatan pembelajaran biasa. 2) ada interaksi antara belajar dengan kemampuan matematika siswa terhadap peningkatan kemampuan koneksi matematika dan pemikiran positif siswa. 3) untuk menentukan bagaimana proses jawaban yang dilakukan oleh siswa dalam pemecahan masalah dengan menggunakan pembelajaran kontekstual dan pendekatan pembelajaran biasa. Jenis penelitian ini adalah eksperimen semu. Populasi penelitian ini seluruh siswa kelas X SMK Tehnical di Medan dengan akreditasi B dan sampel dipilih secara acak. Dimana X Nautic sebagai kelas eksperimen dan X Tehnical sebagai kelas kontrol yang masing-masing terdiri dari 34 siswa. Instrumen yang digunakan terdiri dari: (1) menguji kemampuan matematika awal siswa, (2) tes untuk koneksi matematis dan (3) skala untuk berpikir positif. Analisis data dilakukan dengan menggunakan ANAVA 2 Jalur. Hasil penelitian menunjukkan bahwa (1) peningkatan kemampuan koneksi matematika dan berpikir positif siswa dengan menggunakan Pembelajaran Kontekstual lebih tinggi daripada menggunakan pendekatan pembelajaran biasa, (2) tidak ada interaksi antara pembelajaran dan kemampuan awal matematika siswa terhadap peningkatan kemampuan matematika dan pemikiran positif siswa. Peneliti menyarankan untuk menggunakan Pembelajaran Kontekstual sebagai cara alternatif bagi para guru untuk meningkatkan kemampuan koneksi matematis dan pemikiran positif siswa.
\end{abstract}

Kata Kunci: Pembelajaran Kontekstual, Kemampuan Koneksi Matematika, dan Sikap Positif Siswa

\section{PENDAHULUAN}

Perkembangan ilmu pengetahuan dan teknologi (IPTEK) sekarang ini membawa perubahan gaya hidup manusia baik dalam bidang sosial, sains dan teknologi, budaya, 
kepercayaan, impormasi maupun pendidikan. Hal ini merupakan tantangan dan kesempatan untuk dapat meningkatkan mutu sumber daya manusia agar dapat bersaing dalam dunia yang penuh dengan persaingan hidup. Departemen Pendidikan dan Kebudayaan terus melakukan pembaharuan dan inovasi dalam bidang pendidikan, salah satunya adalah pembaharuan dan inovasi kurikulum, yakni lahirnya kurikulum 2013 yang merupakan pergeseran paradigma pembangunan dari abad ke-20 menuju abad ke- 21 .

Matematika memegang peranan yang sangat penting dalam peningkatan sumber daya manusia. Pembelajaran matematika memberikan siswa kemampuan menalar yang logis, sistematik, kritis dan cermat, menumbuhkan rasa percaya diri, dan rasa keindahan terhadap keteraturan sifat matematika, serta mengembangkan sikap objektif dan terbuka yang sangat diperlukan dalam menghadapi masa depan yang senantiasa berubah. Cockroft (Abdnurrahman, 2009:253) mengemukakan bahwa: "Matematika perlu diajarkan kepada siswa karena (1) selalu digunakan dalam segala segi kehidupan; (2) semua bidang kehidupan memerlukan keterampilan matematika sesuai; (3) merupakan sarana komunikasi yang kuat, singkat dan jelas; (4) dapat digunakan untuk menyajikan informasi dalam berbagai cara; dan (5) memberikan kepuasaan terhadap usaha memecahkan masalah yang menantang."

Meningkatkan kualitas pembelajaran khususnya mata pelajaran matematika yakni dengan memberikan pelatihan-pelatihan baik di tingkat pusat melalui Pusat Pengembangan Penataran Guru Matematika (BP3G Matematika) maupun di tingkat daerah melalui Musyawarah Guru Mata Pelajaran (MGMP) telah dilakukan. Demikian juga halnya program sertifikasi guru yang di laksanakan sekitar 10 tahun terakhir ini yang tujuan untuk meningkatkan kualitas guru.

Standar proses dari pembelajaran matematika menurut National CouncilTeachers of Mathematics (NCTM 2000:29) adalah problem solving(pemecahan masalah), reasoning dan proof (penalaran dan pembuktian), communication (komunikasi), connection (koneksi) dan representation (representasi). Koneksi matematik merupakan bagian dari standar proses matematika yang sangat penting karena dalam proses pembelajaran maupun penyelesaian masalah, siswa dimungkinkan untuk menghubungakan suatu keterampilan dan pengalaman yang mereka miliki untuk diterapkan dalam penyelesaian soal-soal yang tidak rutin. Jika siswa hanya mampu rumus saja tetapi tidak dapat mengkaitkan masalah yang di berikan dengan materi-materi sebelumnya ataupun dengan bidang yang lain, pastilah masalah tersebut tidak dapat di selesaikan.

Yuniawati (2011:108) menemukan bahwa kemampuan siswa untuk melakukan koneksi matematik tergolong masih rendah, akibatnya prestasi belajar matematika siswa juga masih rendah. Kenyataan yang sama dinyatakan Ruspiani (Sulistyaningsih dkk, 2013:122) mengungkapkan bahwa rata-rata kemampuan koneksi matematika siswa sekolah menengah rendah. nilai rata-ratanya kurang dari 60 pada skor 100, yaitu sekitar 22,2\% untuk koneksi matematika siswa dengan pokok bahasan lain, 44,9 \% untuk koneksi matematika siswa dengan bidang studi lain, dan 7,3\% untuk koneksi matematika dengan kehidupan sehari-hari.

Permasalahan tentang koneksi matematika siswa ini harus segera ditangani, agar kemampuan siswa terhadap kompetensi dasar yang diinginkan kurikulum dapat tercapai. Melalaui koneksi matematik maka konsep pemikiran dan wawasan siswa semakin terbuka terhadap matematika, tidak hanya berfokus pada topik tertentu saja yang dipelajari, sehingga akan menimbulkan sikap positif terhadap matematika itu sendiri.

Bruner (Sulistyaningsih dkk, 2013:122) mengungkapkan bahwa selain nalar, yang sangat mempengaruhi prestasi belajar peserta didik dalam matematika adalah kemampuan peserta didik dalam koneksi matematik. Selanjutnya Bruner dalam (Sulistyaningsih dkk, 2013:122) juga mengungkapkan bahwa tak ada konsep atau operasi lain dalam suatu 
sistem. Sejalan dengan itu Jahinoma (2013:209) menyatakan bahwa konsep-konsep matematika merupakan konsep yang saling berkaitan haruslh meresap dalam pembelajaran matematika di sekolah. Berdasarkan hal tersebut bahwa kemampuan koneksi matematik menjadi fondasi agar siswa dapat melanjutkan pada topik-topik selanjutnya dalam proses pembelajaran matematika di sekolah.

Oleh karena sangat penting kemampuan koneksi matematik dikuasai oleh siswa, sementara temuan di lapangan bahwa kemampuan tersebut masih rendah.Maka untuk menumbuhkembangkan koneksi dalam pembelajaran matematika, guru harus mengupayakan pembelajaran dengan menggunakan model-model belajar yang dapat memberi peluang dan mendorong siswa untuk melatih kemampuan koneksi matematik siswa. Melalui pembelajaran yang proses diawali dengan menghadapkan masalah nyata akan mengarahkan kepada kemampuan koneksi matematik siswa, baik dengan pembelajaran lain, maupun koneksi matematika dalam kehidupan sehari-hari.

Selain kemampuan koneksi matematik terdapat satu hal yang penting lainnya yang sangat berpengaruh terhadap prestasi belajar matematika yaitu sikap positif siswa yang harus dimiliki oleh siswa, diantaranya menyenangi matematika, menghargai keindahan matematika, memiliki keingitahuan yang tinggi dan senang belajar matematika. Namun kenyataan yang terjadi sangat berbeda, banyak siswa kurang tertarik dalam pembelajaran matematika. Siswa cenderung merasa bosan atau jenuh, bahkan ada yang merasa takut jika mengikuti pelajaran matematika.

Dari hasil observasi melalui angket sikap yang di berikan kepada 30 orang siswa SMK Pelayaran Samudera Indonesia pada saat pemberian soal matematika terdapat presentasi sikap positif terhadap matematika yang masih dibawah $50 \%$ yaitu sebesar 35,67 $\%$ dan siswa yang mempunyai sikap positif terhadap matematika adalah siswa yang hanya memperoleh nilai matematika tinggi dari hasil raport semester sebelumnya. Oleh Karena itu sikap positif siswa terhadapmatematika sungguh suatu hal yang harus ada dalam diri siswa guna untuk meningkatkan prestasi siswa dalam matematika.

Mandur dkk (2013:4) menyatakan sikap siswa terhadap matematika tampak ketika siswa menyelesaikan tugas matematika, apakah dikerjakan dengan percaya diri, tanggung jawab, tekun, pantang putus asa, merasa tertantang, memiliki kemauan untuk mencari cara lain dan melakukan refleksi terhadap cara berpikir yang telah dilakukan. Jadi sikap positif siswa terhadap matematika dapat meningkatkan hasil belajar matematika siswa.

Jadi, pemilihan model pembelajaran harus disesuaikan dengan kehidupan sehari-hari (kontekstual) dan tingkat kognitif siswa. Johnson (2010: 34) menyatakan pembelajaran dan pengajaran kontekstual sebagai suatu system mengajar, didasarkan pada pikiran bahwa makna muncul dari hubungan antara isi dan konteksnya. Melalui model pembelajaran kontekstual ini diharapkan siswa lebih memahami konsep-konsep matematika yang diberikan dalam pembelajaran, dan tahu kegunaannya.

Selanjutnya Munaka dkk (2009:48) mengemukakan di dalam pembelajaran kontekstual, siswa dibantu untuk melihat makna dari pelajaran sekolah yang mereka pelajari dengan menghubungkan pelajaran tersebut dengan konteks kehidupan sehari-hari. Hal yang sama dinyatakan Suprijono (2009:78) mengemukakan bahwa pembelajaran kontekstual $(C T L)$ merupakan konsep yang membantu guru mengaitkan antara materi yang diajarkan dengan situasi dunia nyata dan mendorong peserta didik membuat hubungan antara pengetahuan yang dimiliki dengan penerapan dalam kehidupan mereka sebagai anggota keluarga dan masyarakat. . Ini menunjukan pembelajaran kontekstual merupakan prosedur pendidikan yang bertujuan membantu peserta didik memahami makna bahan pelajaran yang mereka pelajari dengan cara menghubungkannya dengan konteks kehidupan mereka sendiri. Jadi, pembelajaran kontekstual adalah usaha untuk membuat siswa aktif 
dalam memompa kemampuan diri tanpa merugi dari segi manfaat, sebab siswa berusaha mempelajari konsep sekaligus menerapkan dan mengaitkannya dengan dunia nyata.

Sanjaya (2011:262) menyatakan bahwa pendekatan kontekstual memiliki tujuh komponen yaitu: konstruktivisme, inkuiri, bertanya, pemodelan, refleksi dan penilaian sebenarnya. Konstruktivisme merupakan landasan filosofi pembelajaran kontekstual. Dalam proses pembelajaran, siswa membangun sendiri pengetahuan mereka melalui keterlibatan aktif dalam proses pembelajaran. Sangat memungkinkan pembelajaran kontekstual dapat meningkatkan kemampuan koneksi matematik siswa dengan mengoptimalkan komponen tersebut.

Dengan penggunaan konteks dalam belajar matematika, tentunya akan memberikan motivasi pada siswa, bahwa belajar matematika memiliki manfaat dan kegunaan yang sangat besar dalam kehidupan keseharian mereka. Menurut Sears (Ortiz, 2001:360) berpendapat: "Contextual teaching and learning is an instructional approach that allows teachers to relate school subject matter to real world situations. It is based on situated cognition theory and brain based research and holds that most people learn best when concepts are presented in a situation or context that is familiar and relevant to the learner".

Maksudnya pembelajaran kontekstual adalah pembelajaran yang memungkinkan guru untuk menghubungkan siswa dengan situasi dunia nyata. Hal ini didasarkan pada teori kognisi bahwa kebanyakan orang belajar lebih baik jika konsep disajikan dalam situasi atau konteks yang akrab dan relevan dengan pelajar.

Selain itu, dengan pembelajaran kontekstual siswa juga akan terlatih menemukan apa secara mandiri atau dengan bimbingan guru. Sehingga apa yang ditulis dan dipelajari siswa akan menjadi lebih bermakna dalam ingatannya dan akan menumbuhkan motivasinya dalam mempelajari matematika. Selanjutnya Berns and Patricia (2001:2) menyatakan: "Contextual teaching and learning is a conception of teching and learning that helps teacher relate subject matter content to real world situation; and motivates students to make connections between knowledge and it's applications to their lives as family members, citizens, and workers and engage in the hard work that learning requires".

Maksudnya kontekstual adalah konsep pembelajaran yang di rancang agar guru menghubungkan materi pelajaran dengan situasi dunia nyata dan memotivasi siswa untuk menghubungkan antara pengetahuan dengan aplikasinya dalam kehidupan sehari-hari. Sehingga penerapan kontekstual harus diperluas untuk seluruh disiplin ilmu sehingga siswa memperoleh perspektif kehidupan nyata.

Menyimak kesenjangan antara harapan dan kenyataan di lapangan pendidikan matematika dewasa ini, khususnya pada sekolah SMK Pelayaran Samudera Indonesia. Dimana masih terlihat jelas rendahnya kemampuan koneksi matematik dan sikap positif siswa terhadap matematika. Hal ini disebabkan karena kurang antusiasnya siswa dalam proses pembelajaran matematika yang selalu monoton. Melalui observasi guru lebih cenderung melakukan proses pembelajaran biasa. Sehingga siswa kurang mengetahui seberapa penting matematika dalam kehidupan sehari-hari sehingga siswa tidak tertarik mengikuti proses pembelajaran matematika dengan baik. Jelas sikap seperti ini tidak menumbuhkan peningkatan kemampuan matematik siswa khususnya kemampuan koneksi matematik siswa di sekolah tersebut. Karena jika sikap positif siswa terhadap sesuatu baik diharapkan hasil yang baik pula dari proses tersebut.

Mengingat matematika merupakan dasar dan bekal untuk mempelajari berbagai ilmu, juga mengingat matematika tersusun secara hierarkis, maka kemampuan awal matematika yang dimiliki siswa peserta didik akan memberikan sumbangan yang besar dalam memprediksi keberhasilan belajar siswa selanjutnya. Seperti yang diungkapkan Fajar (2010), kemampuan awal merupakan prasyarat yang harus dimiliki siswa agar dapat mengikuti pelajaran yang lancar. Hal ini disebabkan materi pelajaran yang ada disusun 
secara terstruktur sehingga apabila seseorang mengalami kesulitan pada pokok bahasan awal, maka otomatis akan kesulitan dalam mempelajari pokok bahasan selanjutnya. Sebaliknya, siswa yang mempunyai latar belakang kemampuan awal yang baik akan dapat mengikuti pelajaran dengan baik pula.

Kemampuan awal matematika siswa dalam penelitian ini dikategorikan kedalam tiga kelompok yaitu: tinggi, sedang dan rendah. Adapun tujuan pengelompokan siswa berdasarkan kemampuan awal matematika siswa adalah untuk melihat adakah pengaruh bersama antara pembelajaran yang digunakan dan kemampuan awal siswa terhadap peningkatan koneksi matematik dan sikap positif siswa.Bagaimanapun penerapan pembelajaran kontekstual terhadap kemampuan awal matematika siswa yang berbeda, pencapaian hasil belajar siswa diprediksi akan berbeda pula. Sebagaimana Wijaya (Suherman, 2001:23) mengatakan keberhasilan suatu program pengajaran tidak disebabkan oleh satu macam sumber daya, tetapi disebabkan oleh perpaduan antara berbagai sumbersumber daya yang saling mendukung menjadi satu system yang integral.

Maka berdasarkan uraian diatas permasalahan yang akan diungkap dalam penelitian dan dicari penyelesaian adalah 1) Apakah peningkatan kemampuan koneksi matematik antara siswa yang menggunakan pembelajaran kontekstual lebih tinggi dari pada yang menggunakan pembelajaran biasa? 2) Apakah peningkatan sikap positif terhadap matematika antara siswa yang mengikuti pembelajaran kontekstual lebih tinggi daripada yang mengikuti pembelajaran biasa? 3) Apakah terdapat interaksi antara pembelajaran dengan kemampuan awal matematika siswa terhadap peningkatan kemampuan koneksi matematik siswa? 4) Apakah terdapat interaksi antara pembelajaran dengan kemampuan awal matematika siswa terhadap peningkatan sikap positif siswa?.

\section{METODE}

Penelitain ini adalah penelitian kuasi eksperimen dengan desain kelompok pretes postes. (Borg and Gall, 1983) yang digambarkan sebagai berikut:

\begin{tabular}{lll}
$\mathrm{O}$ & $\mathrm{X}$ & $\mathrm{O}$ \\
\hline $\mathrm{O}$ & $\mathrm{O}$
\end{tabular}

Keterangan:

O: Pretes dan Postes

X: Perlakuan yang diberikan pada kelas eksperimen yaitu pembelajaran kontekstual.

Tujuan penelitian ini untuk meningkatkan kemampuan koneksi matematik dan sikap positif siswa SMK Pelayaran Medan dengan menggunakan pembelajaran kontekstual. Penelitian ini diadakan di SMK Pelayaran Samudera Indonesia Medan yang dilakukan sebanyak 5 kali pertemuan pada masing-masing kelas. Pengambilan sampel dilakukan secara acak, dimana pada kelas eksperimen adalah kelas X Nautika dan kelas control adalah kelas X Teknika dimana masing-masing berjumlah 34 orang siswa. Instrument yang digunakan dalam pengambilan data adalah tes kemampuan awal matematika dan angket skala sikap positif siswa. Analisis data dalam penelitian ini terdiri dari pengujian normalitas, pengujian homogenitas, pengujian perbedaan rata-rata, perhitungan indeks gain, dan pengujian hipotesis. Pengujian hipotesis statistic dalam enelitian ini menggunkan rumus Anava Dua Jalur.

\section{HASIL DAN PEMBAHASAN}

Kemampuan Koneksi Matematik

Data kemampuan koneksi matematik yang diperoleh dan dianalisis untuk mengetahui kemampuan koneksi matematik sebelum dan setelah pemberian perlakuan pembelajaran. 
Dari data ini diperoleh hasil pretes dan postes kemampuan koneksi dan N-gainnya. Rerata gain yang merupakan gambaran peningkatan kemampuan koneksi matematik dengan pembelajaran kontekstual maupun dengan pembelajaran biasa. Hasil rangkuman disajikan pada tabel berikut:

Tabel 1. Kemampuan Koneksi Matematik Berdasarkan Pembelajaran dan Kemampuan Awal Matematika

\begin{tabular}{|c|c|c|c|c|c|}
\hline \multirow{2}{*}{ Pembelajaran } & \multirow{2}{*}{$\begin{array}{c}\text { Kemampuan } \\
\text { Matematik } \\
\text { Siswa }\end{array}$} & \multicolumn{4}{|c|}{ Kemampuan Koneksi Matematik } \\
\hline & & $\bar{X}$ & Std & Min & $\operatorname{Max}$ \\
\hline \multirow{3}{*}{ Kontekstual } & Tinggi (5) & 0,67164 & 0,1935 & 0.47806 & 1 \\
\hline & Sedang (22) & 0,61851 & 0,127 & 0.491706 & 14,067 \\
\hline & Rendah (7) & 0,56921 & 0,094744 & 0.474466 & 0,47446 \\
\hline \multicolumn{2}{|c|}{ Total } & 0,621 & 0,138351 & 0,760825 & 0,48141 \\
\hline \multirow{3}{*}{ Biasa } & Tinggi (7) & 0,561 & 0,071 & 0,631752 & 0,48969 \\
\hline & Sedang (22) & 0,469 & 0.159 & 0,627427 & 0,31024 \\
\hline & Rendah (5) & 0,336 & 0,038 & 0,373752 & 0,29802 \\
\hline \multicolumn{2}{|c|}{ Total } & 0,45514 & 0.089160 & 0,544310 & 0,36599 \\
\hline
\end{tabular}

Dari tabel diatas peningkatan kemampuan koneksi matematik siswa dengan menggunakan belajaran kontekstual (CTL) mempunyai rata-rata dan standar deviasi untuk kelompok tinggi 0,671 dan 0,1935, sedang 0,618 dan 0,127, rendah 0,569 dan 0,094. Sedangkan untuk peningkatan kemampuan koneksi matematik siswa dengan menggunakan pembelajaran biasa yaitu: kelompok tinggi mempunyai nilai 0,561 dan 0,071, kelompok sedang 0,469 dan 0.159, kelompok rendah 0,336 dan 0,038. Jadi dapat dilihat rata-rata peningkatan kemampuan koneksi matematik siswa dengan pembelajaran kontesktual (CTL) lebih tinggi jika dibandingkan dengan gain ternormalisasi kemampuan koneksi matematik dengan pembelajaran biasa (PB). Hasil pengujian menunjukkan bahwa kelompok data gain kemampuan koneksi matematik berasal dari popuasi yang berdistribusi normal dengan varians masing-masing pasangan kelompok data kelompok data homogen, maka selanjutnya dilakukan analisis statistik Anava Dua Jalur untuk melihat peningkatan kemampuan koneksi matematik yang tertera pada tabel berikut:

Tabel 2. Uji Anava Dua Jalur data Peningkatan Kemampuan Koneksi Matematik

Tests of Between-Subjects Effects

\begin{tabular}{cccccc}
\multicolumn{6}{c}{ Dependent Variable: GAIN } \\
\hline Source & $\begin{array}{c}\text { Type III Sum of } \\
\text { Squares }\end{array}$ & $\mathrm{df}$ & Mean Square & $\mathrm{F}$ & Sig. \\
\hline Corrected Model & $.551^{\mathrm{a}}$ & 5 & .110 & 6.178 & .000 \\
Intercept & 13.390 & 1 & 13.390 & 750.785 & .000 \\
KAM & .157 & 2 & .079 & 4.413 & .016 \\
KELAS & .314 & 1 & .314 & 17.611 & .000 \\
KAM * KELAS & .024 & 2 & .012 & .664 & .519 \\
Error & 1.106 & 62 & .018 & & \\
Total & 21.646 & 68 & & & \\
Corrected Total & 1.657 & 67 & & & \\
\hline
\end{tabular}

Berdasarkan Tabel diatas, dapat diketahui bahwa F pada faktor pembelajaran (CTL dan PB) sebesar 17,611 dengan nilai signifikansi 0,000 lebih kecil dari taraf signifikansi 0,05, sehingga $\mathrm{H}_{\mathrm{o}}$ ditolak. Dengan kata lain, terdapat peningkatan kemampuan koneksi matematik antara siswa yang diberi pembelajaran kontekstual (CTL) dibandingkan dengan siswa yang diberi pembelajaran biasa (PB). Pada Tabel 2 terlihat juga faktor pembelajaran yang berhubungan dengan kemampuan siswa diperoleh nilai $\mathrm{F}$ sebesar 0.664 dengan nilai signifikansi sebesar 0,519 lebih besar dari taraf signifikansi yaitu 0,05 , sehingga $\mathrm{H}_{0}$ 
diterima. Maka dapat disimpulkan bahwa tidak terdapat interaksi antara pembelajaran (CTL dan PB) dengan kemampuan awal siswa (tinggi, sedang dan rendah) terhadap peningkatan kemampuan koneksi matematik siswa. Dengan kata lain, peningkatan kemampuan koneksi disebabkan oleh perbedaan pembelajaran yang digunakan bukan karena kemampuan matematika siswa. Secara grafik, interaksi tersebut dapat dilihat pada Gambar 1.

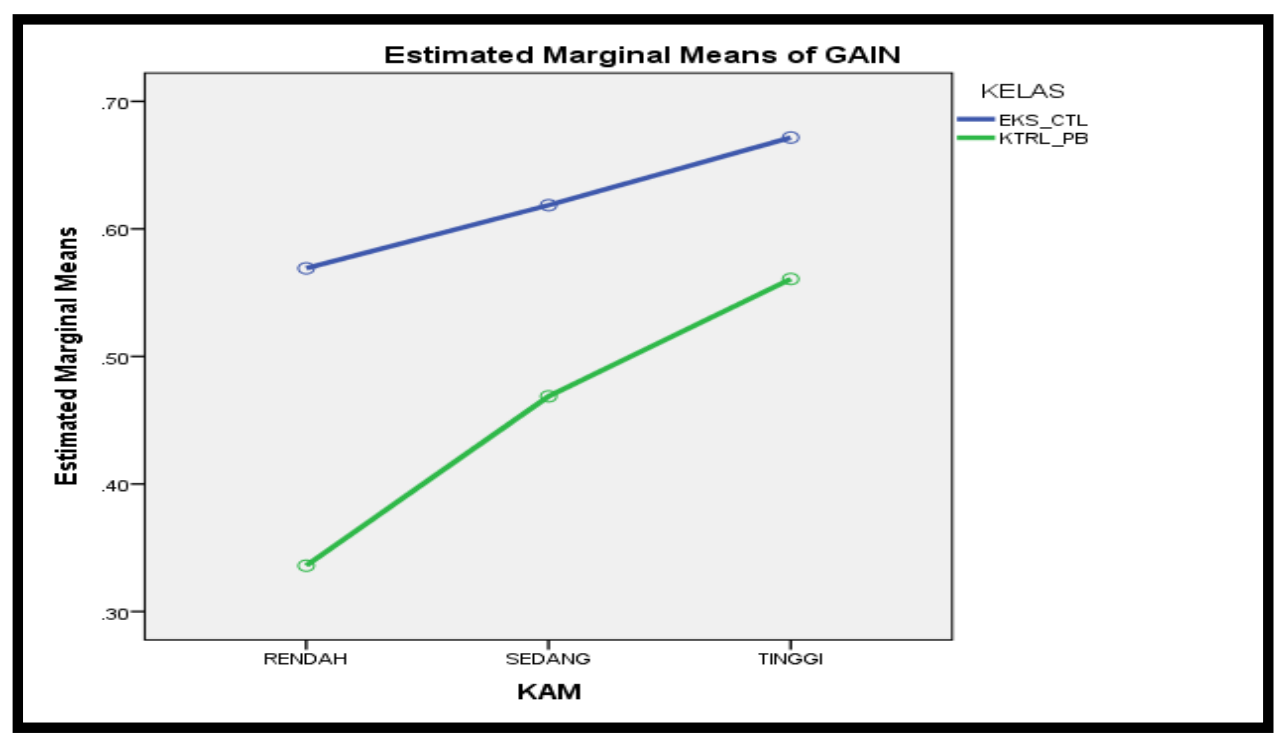

Gambar 1. Interaksi antara Faktor Pembelajaran dengan Faktor Kemampuan Matematika Siswa Terhadap Peningkatan Kemampuan Koneksi Matematik Siswa

Berdasarkan Gambar 1 diatas terlihat bahwa tidak terdapat interaksi antara pembelajaran dengan KAM (tinggi, sedang dan rendah) terhadap peningkatan koneksi matematik masalah siswa. Dari rata-rata gain ternormalisasi terlihat bahwa kemampuan koneksi matematik yang menggunakan pembelajaran kontekstual yaitu: kemampuan tinggi $(0,67)$, kemampuan sedang $(0,62)$ dan kemampuan rendah $(0,57)$ lebih tinggi jika dibandingkan dengan siswa yang menggunakan pembelajaran biasa yaitu: kemampuan tinggi $(0,56)$, kemampuan sedang $(0,47)$ dan kemampuan rendah $(0,34)$. Selanjutnya, selisih rata-rata kemampuan koneksi matematikantara siswa yang diberi pembelajaran kontekstual (CTL) dan pembelajaran biasa (PB) berturut-turut untuk siswa berkemampuan tinggi sebesar 0,116, kemampuan sedang sebesar 0,150 dankemampuan rendah sebesar 0,233 .

Berdasarkan selisih rata-rata tersebut, tampak siswa dengan kategori KAM rendah mendapat "keuntungan lebih besar" dari pembelajaran kontekstual (CTL) yaitu dengan selisih skor 0,233 sementara itu selisih skor untuk siswa berkategori KAM sedang 0,150 dan berkategori KAM tinggi 0,116. Hal ini, berarti bahwa tidak terdapat peningkatan secara bersama-sama yang diberikan oleh pembelajaran dankemampuan awal matematika siswa terhadap kemampuan koneksi matematik siswa.

Selanjutnya dari hasil uji Anava Dua Jalur diketahui bahwa tidak terdapat interaksi antara pembelajaran dan kategori kemampuan awal matematika terhadap peningkatan kemampuan koneksi matematik siswa. Sehingga telah terjadi penerimaan hipotesis statistik. Hal ini menunjukkan bahwa pembelajaran dan kategori kemampuan awal matematika tidak bersama-sama memberikan pengaruh yang signifikan terhadap peningkatan kemampuan koneksi matematik.

Penerimaan ini terjadi bisa saja disebabkan oleh pengelompokkan KAM dalam tinggi, sedang, dan kemampuan awal yang ada (tinggi, sedang, rendah) tidak benar-benar 
menggambarkan kemampuan awal siswa yang sebenarnya, atau pemilihan sampel yang telah dilakukan peneliti kurang menggambarkan apa yang diiinginkan terjadi. Sehingga berakibat kepada data yang diolah dan terjadilah penerimaan hipotesis statistik. Penerimaan ini tentu saja tidak cukup kuat karenanya bagi peneliti selanjutnya dapat melakukan pengujian kembali dengan data yang akurat.

\section{Sikap Positif Siswa}

Data hasil skala angket sikap positifterhadap matematika yang diberikan sebelum dan sesudah pembelajaran baik pembelajaran kontekstual (CTL) maupun pembelajaran biasa (PB) sebanyak 40 butir kepada 34 siswa tiap kelas. Hasil rangkuman rata-rata gain ternormalisasi dari skor sikap positif siswa terhadap matematika dengan pembelajaran kontekstual (CTL) dan pembelajaran biasa (PB) disajikan pada tabel 3 berikut:

Tabel 3. Sikap Positif Siswa Berdasarkan Pembelajaran dan Kemampuan Awal Matematika

\begin{tabular}{cccc}
\hline \multirow{2}{*}{ Pembelajaran } & \multicolumn{2}{c}{$\begin{array}{c}\text { Kemampuan } \\
\text { Matematika } \\
\text { Siswa }\end{array}$} & \multicolumn{2}{c}{ Sikap Positif Matematika } \\
\cline { 2 - 4 } & Tinggi & 0,768 & Std \\
\cline { 2 - 4 } CTL & Sedang & 0,546 & 0,075 \\
\cline { 2 - 4 } & Rendah & 0,256 & 0,080 \\
\cline { 2 - 4 } & Total & 0.523 & 0.064 \\
\hline PB & Tinggi & 0,594 & 0,062 \\
\cline { 2 - 4 } & Sedang & 0,373 & 0,087 \\
\cline { 2 - 4 } & Rendah & 0,198 & 0,022 \\
\cline { 2 - 4 } & Total & 0.388 & 0.057 \\
\hline
\end{tabular}

Berdasarkan Tabel 3 diatas diperoleh bahwa peningkatan sikap positif matematika siswa dengan menggunakan pembelajaran kontekstual (CTL) mempunyai nilai rata-rata dan standar deviasi untuk kemampuan tinggi 0,768 dan 0,075, kemampuan sedang 0,546 dan 0,080, kemampuan rendah 0,256 dan 0,037. Sedangkan untuk peningkatan sikap positif dengan menggunakan pembelajaran biasa yaitu: kemampuan tinggi mempunyai nilai 0,594 dan 0,062, kemampuan sedang 0,373 dan 0,087, kemampuan rendah 0,198 dan 0,022. Pada tabel 3 dapat dilihat bahwa peningkatan kemampuan koneksi matematik untuk ketiga kategori KAM. Pada siswa yang memperoleh pembelajaran kontesktual, peningkatan kemmapuan koneksi matematik untuk kelompok tinggi, sedang dan rendah berada pada kategori rendah. Sedangkan pada siswa yang memperoleh pembelajaran biasa peningkatan koneksi matematik untuk kelompok tinggi, sedang dan rendah berada pada kategori rendah.

Rangkuman hasil uji Anava Dua Jalur untuk peningkatan kemampuan sikap positif disajikan pada tabel 4 sebagai berikut:

Tabel 4. Rangkuman Uji ANAVA Dua Jalur Gain Sikap Positif Siswa

\section{Tests of Between-Subjects Effects}

Dependent Variable: GAIN

\begin{tabular}{lrrrrr}
\hline Source & $\begin{array}{c}\text { Type III Sum of } \\
\text { Squares }\end{array}$ & df & \multicolumn{1}{c}{ Mean Square } & F & Sig. \\
\hline Corrected Model & $1.567^{\mathrm{a}}$ & 5 & .313 & 55.427 & .000 \\
Intercept & 9.644 & 1 & 9.644 & 1705.995 & .000 \\
KAM & 1.202 & 2 & .601 & 106.357 & .000 \\
KELAS & .213 & 1 & .213 & 37.705 & .000 \\
KAM * KELAS & .033 & 2 & .016 & 2.894 & .063 \\
Error & .350 & 62 & .006 & & \\
Total & 16.071 & 68 & & & \\
Corrected Total & 1.917 & 67 & & & \\
\hline
\end{tabular}


Berdasarkan Tabel 4 terlihat bahwa nilai F untuk faktor pembelajaran (CTL dan PB) sebesar 106.357 dengan signifikansi 0,000 lebih kecil dari taraf signifikansi 0,05. Karena itu, hipotesis diterima yang berarti tidak terdapat peningkatan sikap positif antara siswa yang diberi CTL dibandingkan dengan siswa yang diberi pembelajaran biasa ditolak. Dengan kata lain, terdapat peningkatan sikap positif antara siswa yang diberi CTL dibandingkan dengan siswa yang diberi pembelajaran biasa.

Pada Tabel 4 juga terlihat bahwa untuk interaksi antara faktor pembelajaran dan kemampuan diperoleh nilai $\mathrm{F}$ sebesar 2,894 dengan nilai signifikansi 0,063, nilai tersebut lebih besar dari taraf signifikansi 0,05 . Karena itu, hipotesis nol yang menyatakan tidak terdapat interaksi antara pembelajaran dan kemampuan matematika siswa terhadap peningkatan sikap positifsiswa dapat diterima. Dengan kata lain, peningkatan sikap positif disebabkan oleh perbedaan pembelajaran yang digunakan bukan karena kemampuan awal matematika siswa. Secara grafik, interaksi tersebut dapat dilihat pada Gambar 2 berikut:

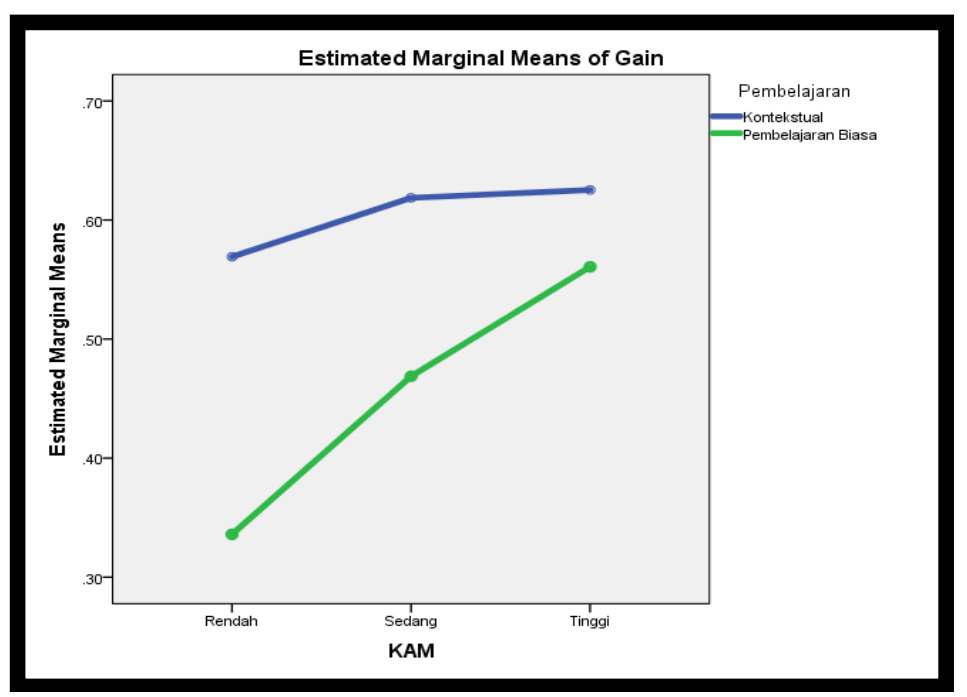

Gambar 2. Interaksi antara Faktor Pembelajaran dengan Faktor Kemampuan Awal Matematika Siswa Terhadap Peningkatan Sikap Positif Siswa.

Berdasarkan Gambar 2 diatas terlihat bahwa tidak ada interaksi antara pembelajaran dengan KAM (tinggi, sedang dan rendah) terhadap peningkatan sikap positif siswa. Dari rata-rata gain ternormalisasi terlihat bahwa sikap positif siswa yang menggunakan pembelajaran kontekstual (CTL) yaitu: kemampuan tinggi $(0,760)$, kemampuan sedang $(0,546)$ dan kemampuan rendah $(0,256)$ lebih besar jika dibandingkan dengan siswa yang menggunakan pembelajaran biasa yaitu: kemampuan tinggi $(0,593)$, kemampuan sedang $(0,373)$ dan kemampuan rendah $(0,198)$. Selanjutnya, selisih rata-rata gain sikap positif antara siswa yang diberi pembelajarn kontekstual (CTL) dan pembelajaran biasa (PB) berturut-turut untuk siswa berkemampuan tinggi sebesar0,174, kemampuan sedang sebesar 0,172 dan kemampuan rendah sebesar 0,057. Sehingga, pembelajaran kontekstual (CTL) lebih tinggi dibandingkan pembelajaran biasa (PB).

Selanjutnya hasil uji anava dua jalur diketahui bahwa tidak terdapat interaksi antara pembelajaran dan kategori kemampuan awal matematik terhadap peningkatan sikap positif siswa. Hal ini menunjukkan bahwa pembelajaran dan karegori kemampuan awal matematik tidak bersama-sama memberikan pengaruh yang signifikan terhadap peningkatan sikap positif siswa. Berdasarkan faktor pembelajaran terdapat perbedaan peningkatan sikap positif siswa. Pada siswa yang memperoleh pembelajaran kontesktual, peningkatan sikap positif siswa lebih baik dibandingkan siswa yang memperoleh pembelajaran biasa. Dengan demikian, dapat disimpukan bahwa pembelajaran mempunyai pengaruh yang signifikan 
terhadap peningkatan sikap positif siswa dibandingkan dengan kemampuan awal matematika.

\section{KESIMPULAN DAN SARAN \\ Kesimpulan}

Berdasarkan hasil analisis, temuan yang telah dikemukakan, diperoleh beberapa kesimpulan sebagai berikut:

1. Peningkatan kemampuan koneksi matematik siswa yang diberi pembelajaran kontekstual lebih tinggi daripada siswa yang diberi pembelajaran biasa.

2. Peningkatan sikap positif siswa yang diberi pembelajaran kontekstual lebih tinggi daripada siswa yang diberi pembelajaran biasa.

3. Tidak terdapat interaksi antara pembelajaran dengan kemampuan awal matematika siswa terhadap peningkatan kemampuan koneksi matematik siswa

4. Tidak terdapat interaksi antara pembelajaran dengan kemampuan awal matematika siswa terhadap peningkatan sikap positif siswa terhadap matematika.

\section{Saran}

1. Dalam setiap pembelajaran guru sebaiknya menciptakan suasana belajar yang memberi kesempatan kepada siswa untuk mengungkapkan gagasan-gagasan matematika dalam bahasa dan cara mereka sendiri, sehingga dalam belajar matematika siswa menjadi berani berargumentasi, lebih percaya diri dan kreatif.

2. Bagi peneliti yang hendak melakukan penelitian dengan model pembelajaran kontekstual, hendaknya melakukan penelitian pada populasi yang lebih besar yang terdiri dari beberapa sekolah agar hasilnya dapat mengenaralisir penggunaan model pembelajaran kontekstualsecara lebih luas pula.

3. Pada peneliti selanjutnya hendaknya dapat menggali lebih jauh mengenai peningkatan koneksi matematik berdasarkan level sekolah ynag berbeda serta melihat bagaimankah pembelajaran ini terhadap kemampuan matematik lainnya seperti penalaran, komunikasi, berpikir kreati dan kemampuan lainnya.

\section{DAFTAR PUSTAKA}

Abdurrahman, M. 2009. PendidikanBagiAnakBerkesulitanBelajar. Jakarta: RinekaCipta

Berns, R.G. and Patricia. (2001). Contextual Teaching and Learning: Preparing Students for The New Economy, No 5.

Jahinoma. 2013. Perbedaan Kemampuan Koneksi dan Pemecahan Masalah Matematika Antara Siswa yang Diberi Pembelajaran Kooperatif Tipe Jigsaw dan Pengajaran Langsung. Prosiding Seminar Nasional Sains dan Pendidikan Sains VIII, Fakultas Sains dan Matematika UKSW Salatiga, 4(1).

Johnson, B, E. 2010. Contextual Teaching \& Learning. Bandung: Kaifa

Mandur, K., Sandra, I.W., Supatra, I. N. 2013. Kontribusi Kemampuan Koneksi, Kemampuan Representasi, dan Disposisi Matematis Terhadap Prestasi Belajar Matematika Siswa SMA Swasta di Kabupaten Manggarai. e-Journal Program Pascasarjana Universitas Pendidikan Ganesha, Vol. 2.

Munaka, F., Zukardi, P. 2009. Meningkatkan Kemampuan Siswa Menyelesaikan Soal Kontekstual Melalui Cooperative Learning di Kelas VIII1 SMP Negeri 2 Pedamaran Oki. Jurnal Pend. Matematika. 3(1).

National Council of Teachers of Mathematics. 2000. Principles andEvaluation Standard for School Mathematics. Reston. VA: NCTM 
Ortiz, A. M. 2001. Engineering Design as a Contextual Learning and Teaching Framework: How Elementary Students Learn Math and Technological. Literacy Tufts University. Medford, Massachusetts, USA

Sanjaya, W. 2011. Strategi Pembelajaran Berorientasi Standar Proses Pendidikan . Jakarta: Kencana

Sulistyaningsih, D., Waluya, S. B., Kartono. 2012. Model Pembelajaran Kooperatif Tipe CIRC dengan Pendekatan Kontruktivisme untuk Meningkatkan Kemampuan Koneksi Matematik. Unnes Journal of Mathematics Education Research, 1(2).

Suprijono, A. 2009. Cooperative Learning; Teori dan Aplikasi PAIKEM. Yogyakarta: Pustaka Pelajar.

Yuniawati. 2011. Penerapan Pembelajaran Matematika dengan Strategi React untuk Meningkatkan Kemampuan Koneksi dan Representasi Matematik Siswa Sekolah Dasar. Jurnal Edisi Khusus, No 2 ISSN 1412-565X 